\title{
Alteration of Oxidative Status in Rats Following Administration of Acrylamide
}

\author{
Hanaa H. El-Sayed ${ }^{1}$, Shawkia S. Abd El- Halim ${ }^{1}$, \\ Gehan M. Morsy ${ }^{2}$ and Ayman El-Sayed El- Adawi ${ }^{3}$ \\ ${ }^{1-}$ National Nutrition Institute. ${ }^{2-}$ Women's college- Ain Shams University. \\ ${ }^{3-}$ Home Economics college- Minufiya University.
}

\section{Abstract}

Introduction: Acrylamide (ACR) is a known industrial neurotoxic and carcinogenic chemical in rodents. The recent discovery of acrylamide in wide variety of commonly consumed foods has energized research efforts worldwide to define toxic mechanisms.

Objective: The present study is carried out to investigate the effect of acrylamide administration on in vivo malondialdehyde (MDA, a product of lipid peroxidation), reduced glutathione (GSH) as well as copper and zinc superoxide dismutase enzyme activity $(\mathrm{Cu} / \mathrm{Zn}$ SOD) of rats.

Material and Methods: Fourteen adult male Sprague Dawley rats were divided into two groups each containing "7" rats. Group 1 served as negative control fed on basal diet and group 2 (positive control) received basal diet and acrylamide $(0.34 \mathrm{~g} / \mathrm{kg}$ diet) for 11 days. Levels of MDA, GSH and activity of SOD were determined in liver, kidneys, brain, heart, testes, spleen and lungs of rats.

Results: ACR treatment significantly increased MDA in all organs; the highest increase was detected in testis $(87.9 \%)$ and heart $(71.5 \%)$ while the lowest one was found in kidneys (28.2\%). On the other hand, GSH levels and SOD activities were significantly reduced in ACR treated rats. However, the reduction of GSH level ranged from $10.2 \%$ to $36.5 \%$. The inhibition of SOD activities were higher in testis (57.3\%) and lungs (38.5\%).

Conclusion: The present study showed that ACR exerts deteriorated effects on oxidative status of rats.

Keywords: Acrylamide -In vivo- Rats- Tissues - Lipid peroxidation - Reduced glutathione- Superoxide dismutase.

\section{Introduction}

Acrylamide $\left(\mathrm{NH}_{2}-\mathrm{C}=\mathrm{O}-\mathrm{CH}-\mathrm{CH}_{2}\right)$, a highly reactive vinyl, water soluble monomer. It does not occur naturally, but is formed from the dehydration of acrylonitrile (Macwilliam, 1978). Scientists in several countries have reported high concentration of ACR in stach-rich foodstuffs. It was also found in various fried, deep-fried and oven- (e.g. chips, crisps and bread, crackers and breakfast cereals) (Tareke et al., 2002), formed by Maillard reaction from reducing sugars (e.g. glucose) and amino acids (e.g. asparagines) (Mottram et al., 2002, Taubert et al., 2004).

Acrylamide is used in the manufacture of polyacrylamide used in municipal and industrial wastewater treatment (Blumenthal et al., 1995), as well as in paper pulp industry (Dearfield et al., 1988). Polyacrylamides are also used in drilling muds, textile and laminating resins, flocculation of ores, friction reduction, soil stabilizers, oil-in-water deemulsifiers, gel chromatography and electrophoresis, photography, dyeing and ceramics, and food processing (Bergmark et al., 1991).

Human exposure to acrylamide primarily comes from dermal contact with solid monomer and inhalation of dust and vapor in the occupation setting. The public may be exposed to acrylamide through the ingestion of drinking water that is contaminated with acrylamide or the intake of acrylamide from foods (Jerry, 2005). It has been also reported that acrylamide was formed in the heating of rodent feed, suggesting that human exposure to acrylamide could occur during the cooking of rodent food (Tareke et al., 2002).

Acrylamide has been observed to produce neurotoxic effects in industrial workers and several species of experimental 
animals (Sobel et al., 1986; Crofton et al., 1996). Other effects of acrylamide exposure include genotoxic, carcinogenic, reproductive and developmental abnormalities (Erdeich and Friedman, 2004, Yang et al., 2005). Acrylamide can also across the placenta and significant concentration reach the conceptus and produce direct developmental and post-natal effects in rodent offspring (Dearfield et al., 1988).

The current study used the in vivo model (rat tissues) to investigate the effect of ACR administration on the oxidative status of different organ tissues of rats (MDA, as a product of lipid peroxidation, reduced $\mathrm{GSH}$ and $\mathrm{Cu} / \mathrm{Zn} \mathrm{SOD}$ ).

\section{Material and Methods}

\section{Chemicals:}

Acrylamide was purchased from Merk- schuchardt chemical company (Hohenbrunn. Germany), with molecular formula $\mathrm{NH}_{2}-\mathrm{C}=\mathrm{O}-\mathrm{CH}-\mathrm{CH}_{2}$ and purity of > 99\%. All other chemicals were of analytical grade.

\section{Animals:}

Fourteen adult male Sprague-Dewily rats (weighing 160-180) were obtained from Vaccine and Immunity Organization, Hellwan farm, Cairo, Egypt. Rats were housed individually in mesh bottomed metallic cages under healthy environmental conditions. Water and diet were provided ad-libitum.

\section{Experimental design:}

Rats were divided into two groups (7rats/ group). Group 1 served as negative control fed basal diet (Philip et al., 1993).Group 2 fed basal diet to which acrylamide is added $(0.34 \mathrm{~g} / \mathrm{kg}$ diet $)$ for 11days as described by (Lehning et al., 2002). . The consumed food and body weights of rats wee recorded twice a week to monitor food intake and body weight gain

-Food intake was calculated as $\mathrm{g} /$ day/rat.

- \% Body weight Change =

Final body weight - Initial body weight

Initial body weight

\section{Biochemical analysis:}

At the end of experimental period (11 days), all rats were anesthetized with diethyl ether after overnight fasting and sacrificed. Liver, kidneys, brain, heart, testes, spleen and lungs were isolated immediately, plotted free from adhering blood, washed with cooled saline and dried between filter paper. All organs were frozen at $-20^{\circ} \mathrm{C}$ till further analysis. Glutathione (GSH) was determined according to Beutler et al. (1963) and Superoxide dismutase (SOD) according to Beauchamp and Fridovich (1971). Malondialdehyde (MDA) was assayed as described by Uchiyama and Mihara (1978).

Statistical analysis: The data were subjected to statistical analysis using computer programme (SPSS (1996). Independent t-test and one-way analysis of variance (ANOVA) were used, the difference was considered significant at $\mathrm{p}$-value $<0.05$ (Zar, 1984).

\section{Results}

The focus of this work was to investigate the alteration of oxidative status in acrylamide treated rats. However, No animal mortality was found in rats treated with acrylamide. Results presented in table (1) indicated that food intake and the gained body weights of rats received acrylamide decreased significantly as compared with negative control, with percentages of $79.4 \%$ and $25.9 \%$ for body weight gain and food intake respectively.

Acrylamide treatment caused a significant increase in MDA levels (table, 2) in tissue homogenates of all examined organs as compared with negative control group. However, this increase was more pronounced in testis $(-87.9 \%)$ and brain $(-76.0 \%)$. The least effect was detected in kidneys $(-28.2 \%)$, while, both liver, spleen $(-51.1 \%)$ and brain \& lung $(-30.6 \%)$ were equally affected.

The effect of ACR administration on GSH levels of different rat organ tissues is illustrated in table (3), GSH levels were significantly depleted in all tissue homogenates as compared with negative control rats. However, the depletion in GSH 
levels were high in kidneys $(-36.5 \%)$ and testis $(-33.5 \%)$ and low in lung $(-10.2 \%)$.

Moreover, SOD activity in tissue homogenates of ACM treated rats (table, 4), was significantly reduced in all organs as compared with the untreated rats. SOD activity in testis and lung were reduced to $57.3 \%, 38.5 \%$ of the normal control respectively, while the depletion of the enzyme activity in the other organs ranged from $23.8 \%$ to $32.4 \%$..

Table (1): Effect of Acrylamide administration on Food intake and body weight gain of rats (mean \pm S.D).

\begin{tabular}{|c|c|c|c|}
\hline Parameter & Negative control & Positive control & $\%$ change \\
\hline $\begin{array}{l}\text { Food intake } \\
\text { (g/ day/rat) }\end{array}$ & $36.7 \pm 0.93$ & $27.2 \pm 2.8 *$ & 25.9 \\
\hline \% Body weight change & $23.3 \pm 1.7$ & $4.8 \pm 0.3^{*}$ & 79.4 \\
\hline
\end{tabular}

*: Significant difference from negative control $(\mathrm{p}<0.05)$

Table (2): Effect of Acrylamide administration on mean MDA levels (n mol/g tissue) of different organ tissues of rats (Mean \pm S.D)

\begin{tabular}{|l|c||c||c||}
\hline Organs & $\begin{array}{c}\text { Negative } \\
\text { control }\end{array}$ & $\begin{array}{c}\text { Positive } \\
\text { control }\end{array}$ & \% Change \\
\hline \hline Liver & $95.7 \pm 13.8$ & $144.6 \pm 17.4^{*}$ & -51.1 \\
\hline \hline Kidneys & $165.3 \pm 24.3$ & $211.9 \pm 15.8^{*}$ & -28.2 \\
\hline \hline Heart & $60.0 \pm 3.6$ & $102.91 \pm 5.7^{*}$ & -71.5 \\
\hline \hline Brain & $217.0 \pm 9.6$ & $382 \pm 6.4^{*}$ & -76.0 \\
\hline \hline Testis & $162.3 \pm 12.0$ & $305.0 \pm 32.9^{*}$ & -87.9 \\
\hline \hline Spleen & $51.7 \pm 5.3$ & $80.19 \pm 9.6^{*}$ & -55.1 \\
\hline \hline Lung & $58.2 \pm 1.6$ & $76.0 \pm 2.7^{*}$ & -30.6 \\
\hline
\end{tabular}

*: Significant difference from negative control $(\mathrm{p}<0.05)$

Table (3): Effect of Acrylamide administration on mean GSH levels (mg/g tissue) of different organ tissues of rats (Mean \pm S.D)

\begin{tabular}{|c||c||c|c||}
\hline \hline Organs & $\begin{array}{c}\text { Negative } \\
\text { control }\end{array}$ & $\begin{array}{c}\text { Positive } \\
\text { control }\end{array}$ & \% Change \\
\hline \hline Liver & $51.8 \pm 7.5$ & $35.8 \pm 2.5^{*}$ & 30.9 \\
\hline \hline Kidneys & $34.8 \pm 5.3$ & $22.1 \pm 1.9^{*}$ & 36.5 \\
\hline \hline Heart & $32.0 \pm 1.4$ & $23.0 \pm 1.4^{*}$ & 28.1 \\
\hline \hline Brain & $31.4 \pm 1.2$ & $21.2 \pm 0.6^{*}$ & 32.5 \\
\hline \hline Testis & $48.1 \pm 5.7$ & $32.0 \pm 4.9^{*}$ & 33.5 \\
\hline \hline Spleen & $33.0 \pm 1.1$ & $25.0 \pm 0.9^{*}$ & 24.2 \\
\hline \hline Lung & $21.6 \pm 1.1$ & $19.4 \pm 1.8^{*}$ & 10.2 \\
\hline
\end{tabular}

*: Significant difference from negative control $(\mathrm{p}<0.05)$ 
Table (4): Effect of Acrylamide administration on mean SOD activity (U/gm tissue) of different organ tissues of rats (Mean \pm S.D)

\begin{tabular}{||c||c||c||c||}
\hline \hline Organs & $\begin{array}{c}\text { Negative } \\
\text { control }\end{array}$ & $\begin{array}{c}\text { Positive } \\
\text { control }\end{array}$ & \% Change \\
\hline \hline Liver & $735.8 \pm 2.5$ & $549.8 \pm 7.1^{*}$ & 25.8 \\
\hline \hline Kidneys & $450.9 \pm 34.1$ & $343.6 \pm 9.15^{*}$ & 23.8 \\
\hline \hline Heart & $487.4 \pm 45.3$ & $329.3 \pm 17.9^{*}$ & 32.5 \\
\hline \hline Brain & $234.4 \pm 13.4$ & $177.2 \pm 4.0^{*}$ & 24.4 \\
\hline \hline Testis & $506.0 \pm 16.4$ & $216.0 \pm 12.8^{*}$ & 57.3 \\
\hline \hline Spleen & $391.4 \pm 17.0$ & $285.4 \pm 22.0^{*}$ & 27.1 \\
\hline Lung & $339.8 \pm 27.3$ & $208.9 \pm 4.3^{*}$ & 38.5 \\
\hline
\end{tabular}

*: Significant difference from negative control $(\mathrm{p}<0.05)$

\section{Discussion}

The decrease in body weight gain obtained in the present work (table, 1) is in agreement with observation of Yang et al. (2005), who found that body weight was significantly lower in acrylamide treated rats than in the normal control animals. This decrease may be related to the significant accompanied decrease in reduced GSH levels in different organ tissues of rats. Martensson et al. (1990) reported that GSH is essential for the function and structural integrity of the gut, and those GSH deficient mice showed sever degradation of jejunum and colonic mucosa and were found to have weight loss and diarrhea.

Free radicals are continuously produced in vivo and there are number of protective antioxidant (e.g. superoxide dismutase, reduced glutathione) for dealing with these toxic substances. The balance between the production and catabolism of oxidants is critical for maintenance of the biological function (Sridevi et al., 1998)

The observed marked increase of MDA levels (product of lipid peroxidation) in different tissues (table, 2) is in agreement with the finding of Yousef and ElDemerdash (2006). However, Srivastava et al. (1983) suggested that enhancement of lipid peroxidation is a consequence of depletion of glutathione to certain critical levels.

A possible role for the participation of oxidative stress in the toxicity of ACR is supported by several observations. A major pathway of ACR metabolism is GSH conjugation (Miller et al., 1982), where acrylamide is oxidized to glycidamide (a reactive epoxide) and undergoes conjugation with glutathione. By depleting GSH, ACR may decrease the antioxidant levels of the cells leading to an overall increase of intracellular ROS and oxidative damage. ACR is also metabolized by cytochrome P450 to generate cyanide ions (Raucy et al., 1993) Administration of cyanide has been found to cause lipid peroxidation in the brain in mice (Johnson et al., 1987).

Beiswanger et al. (1993) reported that reduced GSH levels in brain and liver of rats were significantly decreased follo-wing ACR administration. These findings are in agreement with the present study.

This depletion of GSH levels is related to conjugation of ACR with GSH (as mentioned before). Acrylamide is a highly reactive electrophilic compound with very high water solubility; these properties facilitate its rapid absorption and distribution throughout the body (Solomon et al., 1985). It binds readily to protein thiols (like GSH) and DNA (Bergmark et al., 1991). Depletion of GSH as a result of conjugation with ACR and GSH has been observed in vivo, Edwards (1975) found that treatment with ACR rapidly depleted GSH in rat liver and identified a GSH conjugate of ACR in bile. Dearfield et al., (1988) stated that after absorption, ACR is 
rapidly metabolized primarily by glutathione conjugation and the majority of applied material is excreted within 24 hours. Moreover, Fennell and Friedman (2005) reported that $59 \%$ of the metabolites excreted in urine of rats administered single dose of acrylamide was from acrylamideglutathione conjugation.

Reduction in the activities of SOD in different tissues is in agreement with the finding of Abdel-Wahhab and Ahmed (2004) who found that SOD activity was decreased in brain homogenate of ACR treated rats. On the contrary, Yousef and El-Demerdash (2006) reported that the activity of SOD was increased by ACRtreatment.

The decreased levels of SOD activity may arise from impairment of antioxidant system as a consequence of an abnormality on the antioxidative metabolisms (Mantovani et al., 2002). Iantomasi et al.,(1994) concluded that deterioration of antioxidative glutathione metabolism and increased oxidative damage to proteins and DNA is associated with impaired enzymatic activity of $\mathrm{Cu} / \mathrm{Zn} \mathrm{SOD}$ in patients with Crohn s disease.

\section{Conclusion}

On the basis of the present results, we can conclude that acrylamide administration caused disturbances in the oxidative status and antioxidants of rats as well as a risk of damage to the investigated organs.

\section{References}

1- Abdel-Wahhab $M$ A and Ahmed H H (2004): Protective effects of Korean panax ginseng chromium VI toxicity and free radical generation in rats. J. Ginseng Res., 28(1): 11-17.

2- Beauchamp C and Fridovich I (1971): Superoxide dismutase: Improved assays and an assay applicable to acrylamide gels. Analytical Biochemistry, 44: 276-287.

3- Beiswanger CM, Mandella RD, Graessle TR, Reuhl K R and Lowndes HE (1993): Synergistic neurotoxic effects of styrene oxide and acrylamide: Glutathioneindependent necrosis of cerebellar granule cells. Toxicol. Appl. Pharmacol, 118: 233244.

4- Bergmark E, Calleman $\mathbf{C} \mathbf{J}$ and Costa LG (1991): Formation of hemoglobin adducts of acrylamide and its epoxide metabolite glycidamide in the rat. Toxicol. Appl. Pharmacol., 111: 352-363.

5- Beutler E, Duron $O$ and Kelly B M (1963): The determination of Park et al. (1981) blood glutathione, J. Lab. \& Clin. Med., 61: 882-888.

6- Blumenthal GM, Abel-Rahman AA, Wilmanth KR, Friedman MA and ASbou-Donia MB (1995): Toxicokinitics of a single $50 \mathrm{mg} / \mathrm{kg}$ oral dose of $\left(2,3{ }^{34} \mathrm{C}\right)$ Acrylamide in white leghom hens. Fundam. Appl. Toxicol., 27: 149-153.

7- Crofton KM, Padilla S Tilson H A Anthony DC, Rayman JH and MacPhail RC (1996): The impact of dose rat on the neurotoxicity of acrylamide: The interaction of administered dose, targettissue concentrations, tissue damage and functional effects. Toxicol. Appl. Pharmacol., 139: 165-178.

8- Dearfield KL, Abernathy CO, Ottley MS, Brantner JH and Hayes PF (1988): Acrylamide: its metabolism, developmental and reproductive effects, genotoxicity, and carcinogenicity. Mutation Research, 195: 45-77.

9- Edwards P. M. (1975): The distribution and metabolism of acrylamide and its neurotoxic analogues in rats. Biochem. Pharmacol., 24: 1277-1282.

10- Erdrich L. S. and Friedman M.A. (2004): Epidemiologic evidence for assessing the carcinogenicity of acrylamide. Regul. Toxicol. Pharmacol., 39(2): 150-7.

11- Fennell TR and Friedman MA (2005): Comparison of acrylamide metabolism in humans and rodents. Adv. Exp. Med. Biol., 561: 109-16.

12- Iantomasi T, Marraccini P, Favilli F et al. (1994): Glutathione metabolism in Crohn's disease. Biochem. Med. Metab. Bioch., 58: 87-91.

13- Jerry M R (2005): "The carcinogenicity of acrylamide". Mutation Research/ Genetic Toxicology and Environmental Mutagenesis, 580 (1-2): 3-20.

14- Johnson J D, Conroy W G, Burris K. D, and Isom $G$ E (1987): Peroxidation of brain lipids following cyanide intoxication in mice. Toxicology, 46:21-28

15- Lehning EJ, Balaban CD, Ross JF and LoPachin RM (2003): Acrylamide neurotoxicity. III. Spatiotemporal characteristics of nerve cell damage in forebrain. Neurutox., 24 (1): 125-36.

16- MacWilliam DC (1978): Acrylamide. In: Mark HF, Othmer DF, Overberger CG, Seaborg GT, Eds. Kick-Othmer Encyclopedia of Chemical Technology, 3rd 
Ed, Vol I. New York, John Wiley \& Son, pp 298-311.

17- Mantoveni G, Maccio A, Madeddu C, and et al., (2002): Quantitative evaluation of oxidative stress, chronic inflammatory indices and leptin in cancer patients: Correlation with stage and performance status. Int. J. Cancer, 98: 84-91.

18- Martensson J, Jain A and Meister A (1990): Glutathione is required for intestinal function. Proc. Natl. Acad. Sci., 87: 175-9.

19- Miller MJ, Carter D E and Sipes L G (1982): Pharmacokinetics of acrylamide in Fisher-344 rats. Toxicol. Appl. Pharmacol., 63: 36-44.

20- Mottram DS, Wedzicha BL and Dodson A T (2002): Acrylamide is formed in the Maillard reaction. Nature, 419: 448-449.

21- Raucy JL, Kraner JC and Lasker J M (1993): Bioactivation of halogenated hydrocarbons by cytochrome P4502El. Crit. Rev. Toxicol., 23: 1-20.

22- Reeves R P, Nielsen FH and Fahey Jr GC (1993): Purified diet for laboratory rodents: final report of the AIN .Ad. Writing committee on the reformulation of the AIN-76. A rodent diet. J. Nutr., 123: 1939-1951.

23- Sobel W, Bond C G, Parsons T W and Brenner F E (1986): Acrylamide cohort mortality study. Bri J. Indust. Med., 43: 785-788.

24- Solomon JJ, Fedyk J. and Segal A. (1985): Direct alkylation's of 2'- deoxynuclecosides and DNA following in vitro reaction with acrylamide. Cancer Res., 45: 3465-3470.

25- SPSS (1996): Statistical package for social science computer soft ware version 8
(USA) on an IBM, PC Computer Bailey (1994).

26- Sridevi B, Reddy KV, Reddy SLN (1998): Effect of trivalent and hexavalent chromium on antioxidant enzyme activities and lipid peroxidation in a freshwater field crab, Barytelphusa guerini. Bull. Environ. Contam. Toxicol., 61: 384-390.

27- Srivastava SP, Das $M$ and Seth $P$ R (1983): Enhancement of lipid peroxidation in rat liver on acute exposure to styrene and acrylamide. A consequence of glutathione depletion. Chemico- Biol. Int., 45: 373-380.

28- Tareke E, Ryberg P, Karsson P Ericsson $S$ and Tomqvist $M$ (2002): Analysis of acrylamide, a carcinogen formed in heated foodstuffs. J. Agric. Food Chem., 50: 49985006.

29- Taubert D, Harllinger S, Henkes L, Berkels $R$ and Schoming $E$ (2004): Influence of processing parameters on acrylamide formation during frying of potatoes. J. Agric. Food Chem., 52: 27352739.

30- Uchiyama M and Mihara M (1978): Determination of malonaldehyed precursor in tissues by thiobarbituric acid test. Analytical Biochemistry, 86: 271-278.

31- Yang HJ, Lee SH, Choi JH, Han DU, Chae C, Lee MH, and Han CH. (2005): Toxicological effects of acrylamide on rats testicular gene expression profile. Reprod. Toxicol., 19: 527-534.

32- Yousef $M \quad I$ and El-Demerdash $F$ (2006): Acrylamide-induced oxidative stress and biochemical perturbations in rats. J. of Toxicology, 219: 133-141.

33- Zar JH (1984): Biostatistical analysis. $2^{\text {th }}$ edn. Prencice-Hall, Englewood Cliffs, N.J. pp. 196-198. 


\section{التغير في حالة التأكسد في الجرذان بعد تعاطى الأكرلاميد}

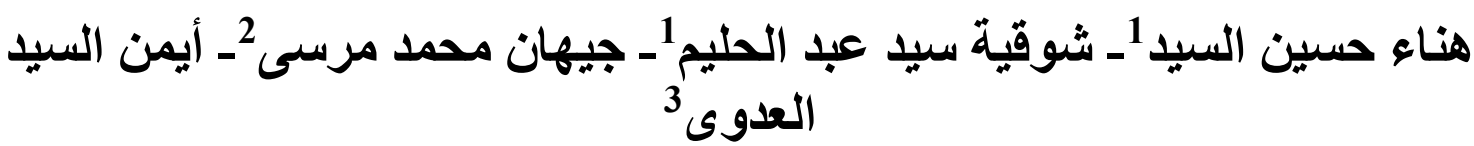
1- المعهد القومي التذذية. 2- كلية البناتـ- جامعة عين شمس. 3- كلية الاقتصاد المنزلي- جامعة المنوفية.

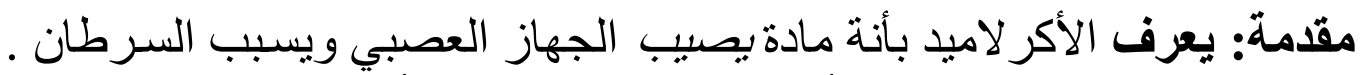

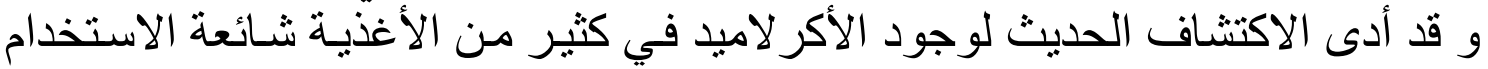

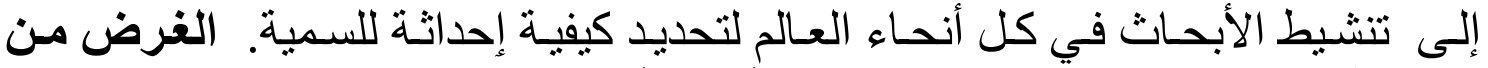

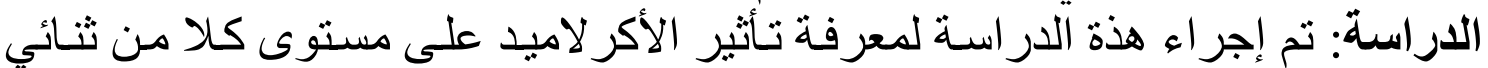

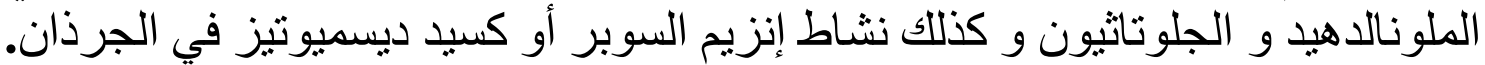

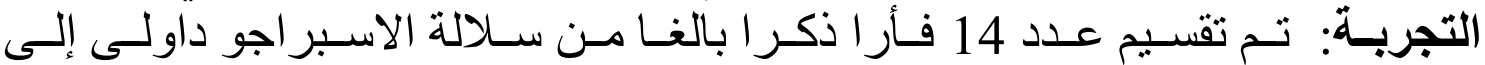

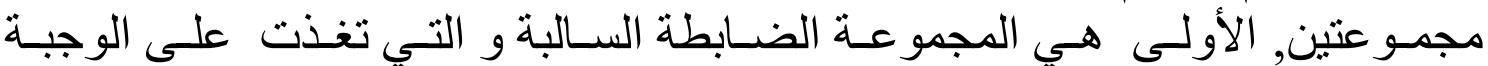

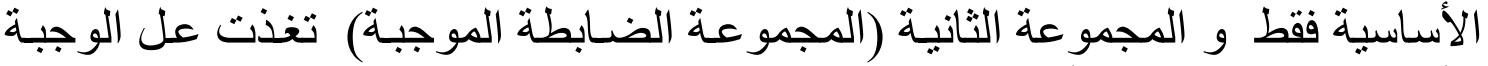

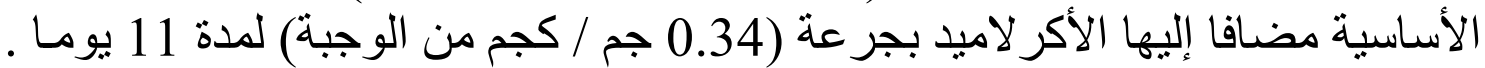

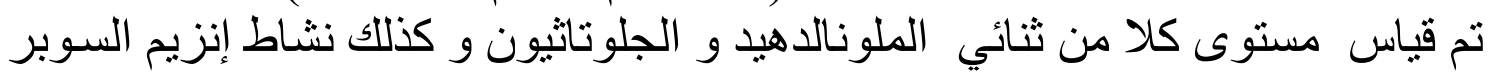

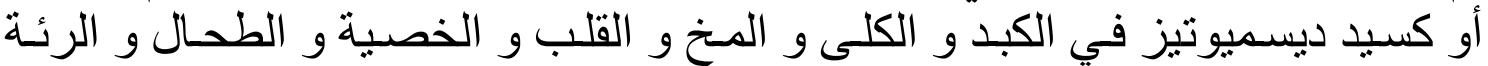

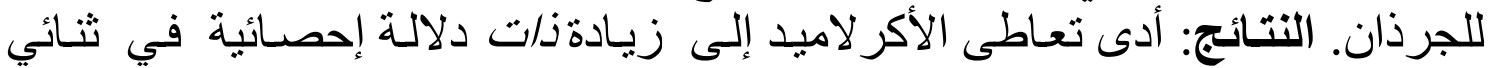

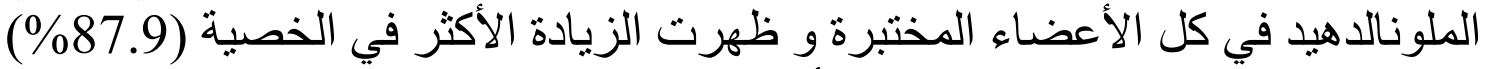

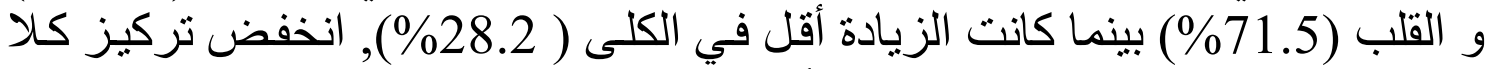

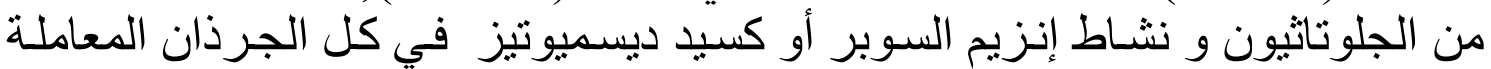

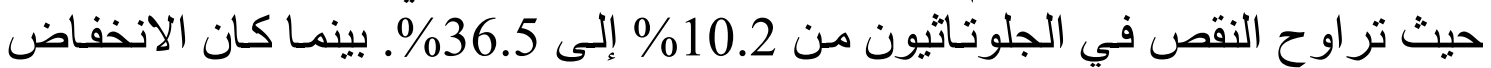

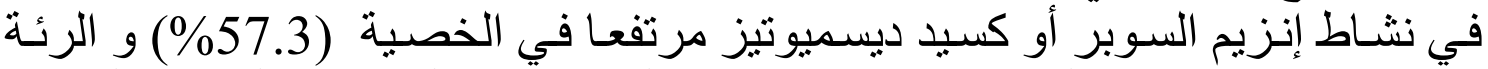

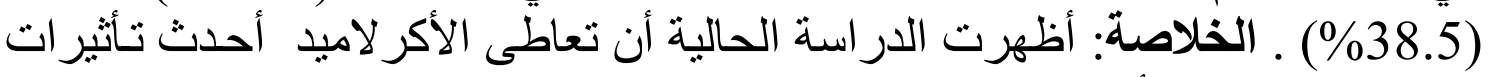
ضارة على حالة التأكسد في الجرذان النان 